\title{
Role of Extracellular Polysaccharide and Endoglucanase in Root Invasion and Colonization of Tomato Plants by Ralstonia solanacearum
}

\author{
Elke Saile, Jeff A. McGarvey, Mark A. Schell, and Timothy P. Denny
}

First, third, and fourth authors: Department of Plant Pathology, Miller Plant Sciences Building, University of Georgia, Athens 30602-7274; and second author: Department of Microbiology, University of Georgia, Athens 30602-2065.

Accepted for publication 15 September 1997.

\begin{abstract}
Saile, E., McGarvey, J. A., Schell, M. A., and Denny, T. P. 1997. Role of extracellular polysaccharide and endoglucanase in root invasion and colonization of tomato plants by Ralstonia solanacearum. Phytopathology 87:1264-1271.

Ralstonia solanacearum is a soilborne plant pathogen that normally invades hosts through their roots and then systemically colonizes aerial tissues. Previous research using wounded stem infection found that the major factor in causing wilt symptoms was the high-molecular-mass acidic extracellular polysaccharide (EPS I), but the $\beta$-1,4-endoglucanase (EG) also contributes to virulence. We investigated the importance of EPS I and EG for invasion and colonization of tomato by infesting soil of

4-week-old potted plants with either a wild-type derivative or genetically well-defined mutants lacking EPS I, EG, or EPS I and EG. Bacteria of all strains were recovered from surface-disinfested roots and hypocotyls as soon as $4 \mathrm{~h}$ after inoculation; that bacteria were present internally was confirmed using immunofluorescence microscopy. However, the EPSminus mutants did not colonize stems as rapidly as the wild type and the EG-minus mutant. Inoculations of wounded petioles also showed that, even though the mutants multiplied as well as the wild type in planta, EPS-minus strains did not spread as well throughout the plant stem. We conclude that poor colonization of stems by EPS-minus strains after petiole inoculation or soil infestation is due to reduced bacterial movement within plant stem tissues.
\end{abstract}

Ralstonia solanacearum (formerly Pseudomonas solanacearum and, more recently, Burkholderia solanacearum) (39) has a wide and still expanding host range that includes several hundred susceptible species in at least 50 different plant families (21). Some of the economically important hosts are potato, tomato, peanut, banana, pepper, eggplant, tobacco, and olive $(4,16)$. The pathogen generally enters a plant through the roots, penetrates the xylem, systemically colonizes the stem, and causes wilt symptoms (20). Although this pathogen has been studied intensively over the last half century, much remains unknown about the saprophytic phase in the life cycle of $R$. solanacearum, the processes of root penetration and infection, and the pathogen factors that facilitate establishment and systemic colonization (34).

Persistence of $R$. solanacearum in soil, either with or without susceptible hosts, has important implications. Some authors report rapid declines in soil populations despite continuous planting of susceptible hosts $(4,20)$. In contrast, Dukes et al. (13) reported heavy losses in tomato planted on newly cleared land in Georgia, suggesting the possibility of long-term survival of the pathogen in soil under brush and timber without the presence of known hosts. Subsequent studies found that $R$. solanacearum can persist in the rhizosphere of weeds (11) and that it may infect the roots of plants previously considered nonhosts $(14,35)$. The reported failure of crop rotations (17) could be interpreted as evidence for the "correlation between long-term survival of $R$. solanacearum and its ability to infect plant roots" (14).

To penetrate the root surface, $R$. solanacearum is thought to require wounds or natural openings. For example, unwounded tomato seedlings grown in root boxes were infected when agar drops containing $R$. solanacearum were applied to points of secondary

Corresponding author: T. P. Denny; E-mail address: tdenny@uga.cc.uga.edu

Publication no. P-1997-1028-01R

(C) 1997 The American Phytopathological Society root emergence, but were not infected when inoculum was placed on areas with an intact epidermis (22). Electron microscopic examination of unwounded roots from tomato plants grown in liquid medium revealed pathogen proliferation at sites of secondary root emergence and partially exfoliated cells of the outer parenchyma layer (33). Based on their light microscopic studies of hydroponically grown tomato plants inoculated with $R$. solanacearum carrying a lacZ reporter fusion, Vasse et al. (38) characterized pathogenesis by a virulent strain as a three-stage process: (i) colonization of the root surface (day 1), (ii) infection of the root cortex (days 2 to 3), and (iii) infection of the vascular parenchyma and invasion of the xylem (day 3 ). Subsequent symptom development can largely be attributed to the high-molecular-mass acidic extracellular polysaccharide (EPS I) made by the pathogen $(10,19$, 28 ). Individual plant cell wall-degrading enzymes such as $\beta-1,4-$ endoglucanase (EG) play minor roles, but, as a group, they are more important (18). However, neither EPS I nor EG is essential for multiplication in planta when $R$. solanacearum is inoculated into wounded stems (8-10,30). Trigalet and Demery (37) found that $h r p$ mutants infected tomato seedlings growing in soil via their roots, but were deficient in colonizing the stem when compared with the wild type and did not cause wilt symptoms $(2,15)$. Thus, the presence of the pathogen inside the plant root or stem (i.e., the ability to infect) does not always result in systemic colonization or disease symptoms.

When assessing virulence or the role of specific bacterial traits in disease development, the choice of inoculation procedure is crucial. The common method of inoculating $R$. solanacearum into wounded stems or roots delivers bacteria to the vascular system, bypassing normal infection routes and, thus, some potential resistance mechanisms. When soil is infested without wounding the roots, or bacteria are added to hydroponic nutrient solutions, the pathogen must take a longer and presumably more natural path of infection. Preliminary soil infestation experiments showed that EPS I-minus $\left(\mathrm{EPS}^{-}\right)$and EG-minus $\left(\mathrm{EG}^{-}\right)$mutants were less virulent than the 
wild type and that an $\mathrm{EPS}^{-} \mathrm{EG}^{-}$double mutant did not cause any symptoms $(8,9)$. However, our earlier experiments were not designed to determine whether reduction in virulence was due to poor survival in soil, a decline in root infection, or reduced colonization of the plant.

We report here the use of defined mutants to reevaluate the role of EPS I and EG in the infection of soil-grown tomato plants via undisturbed roots under growth chamber conditions. We monitored the occurrence of the wild type and the mutants in surface-disinfested primary roots and different stem portions at several time points after soil infestation. Immunofluorescence microscopy added visual evidence for the presence of bacteria inside the primary root cortex only hours after soil infestation. In our experimental system, neither EPS I nor EG was required for ingress of the bacterium into the cortex of the primary root, but the mutants were significantly reduced in their ability to colonize tomato stems.

\section{MATERIALS AND METHODS}

Bacterial strains and culture conditions. The bacteria used in this study are listed in Table 1. Strains were stored in BG broth (1\% Bacto Peptone, $0.1 \%$ Casamino Acids, $0.1 \%$ yeast extract, and $0.5 \%$ glucose) containing $15 \%$ glycerol at $-80^{\circ} \mathrm{C}$. $R$. solanacearum strain AW10 was created by transforming AW1 with total genomic DNA from AWG (6), which has a Tn5 insertion that does not affect virulence, and selecting for kanamycin resistance as described elsewhere $(1,9)$. One kanamycin-resistant transformant that was fully virulent on tomato using a soil infestation method (described below) was selected. Strain PS6-4 was obtained as a spontaneous nalidixic acid-resistant derivative of PS6 (30) that was shown to be as virulent as PS6 using soil infestation.

Escherichia coli strain DH5 $\alpha$ (pUC19) (Gibco BRL, Gaithersburg, MD) was grown at $37^{\circ} \mathrm{C}$ in Luria-Bertani medium (26). $R$. solanacearum cultures were routinely grown at $30^{\circ} \mathrm{C}$ on BGT agar medium (BG plus $1.6 \%$ agar and $0.005 \%$ tetrazolium chloride), amended when appropriate with $20 \mu \mathrm{g}$ of nalidixic acid/ml and $50 \mu \mathrm{g}$ of kanamycin/ml. To prepare inoculum, cultures grown overnight in BG broth were diluted 5,000-fold into minimal medium (6) and the cultures incubated $\left(30^{\circ} \mathrm{C}, 250 \mathrm{rpm}\right)$ until they reached optical density at $600 \mathrm{~nm}\left(\mathrm{OD}_{600}\right) \approx 1.0$; cells were harvested by centrifugation $(7,520 \times g, 20 \mathrm{~min})$ and suspended in sterile water until $\mathrm{OD}_{600}=0.05$. The colony forming units (CFU) per ml of inoculum were determined by dilution-plating on BGT. For detection and quantification of bacteria in plant tissue, dilutions of homogenates were spread on semiselective medium plates made by omitting yeast extract from BGT agar and amending it with $25 \mu \mathrm{g}$ of crystal violet $/ \mathrm{ml}, 50 \mu \mathrm{g}$ of cycloheximide $/ \mathrm{ml}, 20 \mu \mathrm{g}$ of nalidixic $\mathrm{acid} / \mathrm{ml}$, and $50 \mu \mathrm{g}$ of kanamycin $/ \mathrm{ml}$.

Plant inoculation. Tomato seed (Lycopersicon esculentum Mill., cultivar Marion) was surface-disinfested with $70 \%$ ethanol for $1 \mathrm{~min}$, followed by $1.0 \%$ sodium hypochlorite ( $20 \%$ household bleach) for $4 \mathrm{~min}$ and 2 washes in distilled water. The seeds were pregerminated on water agar for 2 days at $30^{\circ} \mathrm{C}$ and then transplanted into $50 \mathrm{~g}$ (92 g wet weight) of a methyl-bromide-fumigated soil mix (soil, sand, perlite, vermiculite, peat, lime, and fertilizer) in 250-ml Styrofoam cups. Cups were transferred to saucers in a growth chamber $\left(30^{\circ} \mathrm{C}, 14 \mathrm{~h}\right.$ of light $)$ and watered twice daily. Plants were fertilized every 10 days with a water-soluble fertilizer (20-20-20 [N-P-K], 3.5 g/liter of water). Plants were used when they were 4 weeks old.

In petiole inoculations, the first leaf above the cotyledons was excised $5 \mathrm{~mm}$ from its base and a $2-\mu \mathrm{l}$ droplet containing $7 \times 10^{4}$ to $9 \times 10^{5} \mathrm{CFU}$ was deposited onto the cut surface. For soil infestations, $50 \mathrm{~g}$ of soil was flooded with $20 \mathrm{ml}$ of a bacterial suspension to give an inoculum concentration of 1 to $3 \times 10^{7} \mathrm{CFU}$ per $\mathrm{g}$ of soil (wet weight); the runoff in the saucers was absorbed by the soil within 3 to $4 \mathrm{~h}$. Pots were arranged in the growth chamber in a completely randomized design.
Virulence of the $R$. solanacearum strains on tomato was measured by the rate at which plants wilted. For each strain, the number of leaves wilted was recorded daily for each of 10 plants and the percentage of wilted leaves calculated. The time required for pairs of strains to cause $50 \%$ wilt was compared with the nonparametric Wilcoxon rank-sum test in PROC NPAR1WAY of SAS, version 6.10 (SAS Institute, Cary, NC).

Test of survival in soil. Inoculum was prepared as described above, and $20 \mathrm{ml}$ of the bacterial suspensions (each with $\mathrm{OD}_{600}=1.0$ ) was poured on the soil to give initial concentrations of 3 to $5 \times 10^{8}$ CFU per $g$ of soil. On days $1,4,8,10$, and 17, four inoculated plants per strain were harvested. To assess the number of viable bacteria in the rhizosphere, "bulk soil" (i.e., soil that is easily dislodged) was removed from the roots by repeatedly shaking the plants for a few seconds after removing them from the Styrofoam cups, leaving the "rhizosphere soil" still attached. The roots plus rhizosphere soil were carefully washed for $1 \mathrm{~min}$ in $100 \mathrm{ml}$ of sterile water in preweighed flasks. The roots were removed, and the flasks containing the rhizosphere soil suspensions were weighed and then shaken on a wrist-action shaker for $1 \mathrm{~h}$. Dilutions from $1 \mathrm{ml}$ of the soil suspension were spread on the semiselective medium to determine the number of viable cells.

Tissue processing and surface disinfestation of plant material. Following petiole inoculation, the $5-\mathrm{mm}$ petiole stubs were removed and $3-\mathrm{cm}$ stem segments were excised above and below the base of the inoculated petiole. After soil infestation, 3-cm stem segments were collected at various distances from 1 to $45 \mathrm{~cm}$ above the ground and surface-sterilized. Stem segments up to $7 \mathrm{~cm}$ above the soil line were sprayed with $95 \%$ ethanol and flamed; segments higher than $7 \mathrm{~cm}$ above the soil line were rinsed with ethanol and allowed to air-dry. Each segment was placed in a sterile bag with $5 \mathrm{ml}$ of phosphate-buffered saline $(0.1 \mathrm{M}$ potassium phosphate buffer [pH 7.3], $0.15 \mathrm{M} \mathrm{NaCl}$, and $3 \mathrm{mM} \mathrm{KCl}$ ) and crushed in a stomacher lab-blender (Seward Medical, London) for $2 \mathrm{~min}$. Dilutions of the homogenates were spread on semiselective medium, and the plates were incubated at $30^{\circ} \mathrm{C}$ for 2 to 7 days. To obtain bacterial counts for the primary roots, entire root systems were first thoroughly washed under running tap water and the stems were cut off $1 \mathrm{~cm}$ above the former soil line. The root systems were immersed for $2 \mathrm{~min}$ in $1.0 \%$ sodium hypochlorite (20\% household bleach), washed under running tap water again, and the lateral roots were cut off. The remaining primary roots were rinsed with 95\% ethanol, air-dried, and processed for viable counts like the stem pieces. In some experiments, the lateral roots also were processed for viable counts.

Immunofluorescence microscopy. The root systems of soil-infested tomato plants were washed under running water, and the lateral roots were removed. Root segments of $5 \mathrm{~mm}$ in length were treated for $1 \mathrm{~h}$ in a solution of $3 \%$ paraformaldehyde and $0.5 \%$ glutaraldehyde in $0.2 \mathrm{M}$ sodium cacodylate buffer ( $\mathrm{pH}$ 7.2). Specimens were washed three times in sodium cacodylate buffer and dehydrated through a graded alcohol series (1-h intervals in 15, $30,45,75$, and $95 \%$ ethanol). After additional overnight incubation in $95 \%$ ethanol, specimens were transferred to $100 \%$ ethanol for $3 \mathrm{~h}$. Specimens were infiltrated with a graded series of Immuno-Bed

TABLE 1. Ralstonia solanacearum strains used in this study

\begin{tabular}{|c|c|c|}
\hline Designation & Relevant characteristics ${ }^{\mathrm{z}}$ & $\begin{array}{l}\text { Reference } \\
\text { or source }\end{array}$ \\
\hline AW1 & $\mathrm{Nx}^{\mathrm{r}}$ derivative of wild-type strain $\mathrm{AW}, \mathrm{EPS}^{+} \mathrm{EG}^{+}$ & 10 \\
\hline AW10 & $\mathrm{AW} 1:: \operatorname{Tn} 5, \mathrm{EPS}^{+} \mathrm{EG}^{+} \mathrm{Nx}^{\mathrm{r}} \mathrm{Km}^{\mathrm{r}}$ & This study \\
\hline AW1-1 & AW1 eps-1::Tn5, EPS ${ }^{-} \mathrm{EG}^{+} \mathrm{Nx}^{\mathrm{r}} \mathrm{Km}^{\mathrm{r}}$ & 10 \\
\hline AW1-2 & AW1-1 egl3::Tn3HoHo1, EPS ${ }^{-} \mathrm{EG}^{-} \mathrm{Nx}^{\mathrm{r}} \mathrm{Km}^{\mathrm{r}} \mathrm{Ap}^{\mathrm{r}}$ & 9 \\
\hline PS6-4 & $\mathrm{Nx}^{\mathrm{r}}$ derivative of $\mathrm{AW}$, egl9::Tn5, EPS ${ }^{+} \mathrm{EG}^{-} \mathrm{Km}^{\mathrm{r}}$ & This study \\
\hline
\end{tabular}

${ }^{\mathrm{z}} \mathrm{Ap}^{\mathrm{r}}, \mathrm{Km}^{\mathrm{r}}$, and $\mathrm{Nx}^{\mathrm{r}}$ designate resistance to ampicillin, kanamycin, and nalidixic acid, respectively. EG = endoglucanase activity, EPS = extracellular polysaccharide. 
infiltration solution (Polysciences, Inc., Warrington, PA) over several days according to the manufacturer's instructions, and then polymerization was conducted on ice in nitrogen gas. Sections $(7 \mu \mathrm{m})$ were made with a glass knife, transferred to a water bath, placed on a glass slide, and air-dried. Slides were washed in $100 \%$ ethanol for 1 to $2 \mathrm{~min}$ and then rehydrated in a graded alcohol series to water. Sections were blocked for $30 \mathrm{~min}$ in $2 \%$ bovine serum albumin fraction V (BSA) (Sigma Chemical Co., St. Louis) in TBST buffer $(20 \mathrm{mM}$ Tris [pH 7.4], $0.85 \% \mathrm{NaCl}, 0.1 \% \mathrm{BSA}$, and $0.05 \%$ Tween 20 ) at room temperature. The primary mouse anti- $\beta$-galactosidase monoclonal antibody (Promega Corp., Madison, WI) was diluted 1:1,000 in TBST, added to the sections, and incubated overnight at $4^{\circ} \mathrm{C}$. Sections were then washed in a stream of TBST, and the secondary goat anti-mouse polyclonal antibody, conjugated to rhodamine (diluted 1:25 in TBST), was added and incubated for $1 \mathrm{~h}$ at room temperature. Sections were washed again in TBST, mounted with two drops of Vectashield (Vector Laboratories, Inc., Burlingame, CA), and examined with a Zeiss Axiophot fluorescence microscope with an HBO 100-W mercury lamp, BP 546-nm excitation filter, FT 580-nm chromatic beam splitter, and LP 590-nm barrier/emission filter (Carl Zeiss, Inc., Thornwood, NY).

Statistical analysis. Statistical analyses were conducted with SAS, version 6.10 (SAS Institute). The degree of host colonization after petiole inoculation was first analyzed using the KruskalWallis test, and then pairs of strains were compared with the nonparametric Wilcoxon rank-sum test in PROC NPAR1WAY. Mean CFUs in the stem segments above and below the inoculated petiole were tested for significant differences with Duncan's multiple range test. To test the effectiveness of surface disinfestation methods, Duncan's multiple range test was used to compare mean CFUs after different treatments. Duncan's multiple range test was also used to analyze invasion of primary roots after soil infestation by testing the mean CFUs from the primary roots. In stem colonization assays after soil infestation, pairwise comparisons of strains were made with the Wilcoxon rank-sum test, and analysis of variance and regressions were performed with PROC GLM (SAS Institute) using a $4 \times 3$ factorial model with 12 observations per cell in a completely randomized design.

\section{RESULTS}

We used a soil infestation method to reexamine the role of EPS I and EG in bacterial wilt of tomato, because it required infection

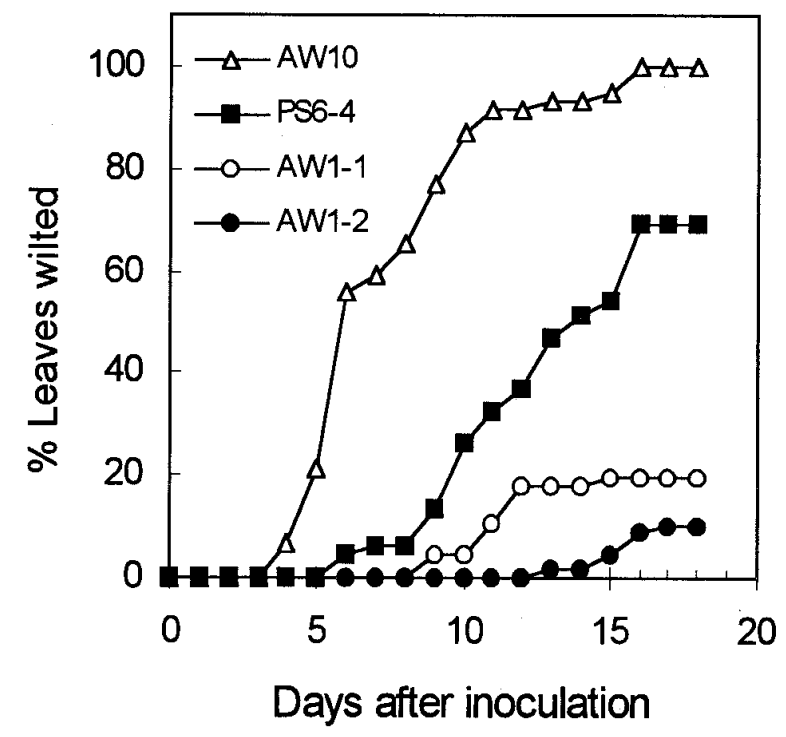

Fig. 1. Virulence of Ralstonia solanacearum strains on tomato plants after soil infestation. Each strain was tested on 10 plants at an inoculum concentration of 1.2 to $2.1 \times 10^{8} \mathrm{CFU}$ per $\mathrm{g}$ of soil (wet weight). of plants through undisturbed roots. To evaluate this inoculation method we assessed (i) the relative virulence of the wild type and the mutant strains to see if the results were similar to those for our standard stem inoculation method, (ii) the soil survival of the wild type and the mutants to determine if bacteria remained equally available for infection, and (iii) the effectiveness of root surface disinfestation methods to see whether we could reliably assess ingress and colonization of the roots.

Virulence of $\boldsymbol{R}$. solanacearum strains after soil infestation. To minimize the differences between the wild type and EPS ${ }^{-}$or $\mathrm{EG}^{-}$mutants, all of the strains contained a Tn5 insertion and were nalidixic acid resistant. The double antibiotic resistance of these strains also facilitated their selective recovery from soil and plant roots. The location of the transposon in AW10 is not known, but the strain was as virulent as AW1 on tomato in three soil infestation experiments (data not shown).

As judged by the onset of wilt and the percentage of leaves wilted, the $\mathrm{EG}^{-}$mutant (PS6-4) was less virulent than AW10, and the EPS $^{-}$mutants (AW1-1 and AW1-2) were the least virulent (Fig. 1). The differences were statistically significant, with AW10 causing 50\% wilt faster than PS6-4 $(P=0.021)$, AW1-1 $(P=$ $0.0002)$, and AW1-2 $(P=0.0001)$. However, looking at single plants rather than at the total number of leaves from 10 plants inoculated with the same strain, each of the mutants could cause complete wilting by day 18; strain PS6-4 wilted seven, AW1-1 wilted two, and AW1-2 wilted one out of 10 plants. The remaining plants were symptomless for all mutant strains.

Survival of $\boldsymbol{R}$. solanacearum in soil. The number of viable cells that could be recovered from rhizosphere soil was determined for three strains up to 17 days after infestation (Fig. 2). Over this short period, there were less than 20 -fold changes from the initial inoculum concentrations, with more than $3 \times 10^{7} \mathrm{CFU}$ per $\mathrm{g}$ of soil being recovered on the last sampling date for each of the strains tested. Since plants inoculated with AW10 showed severe wilt symptoms by day 8 , the transient increase in bacteria recovered from rhizosphere soil in these pots might have been due to their release from roots of wilting plants (22). In five other experi-

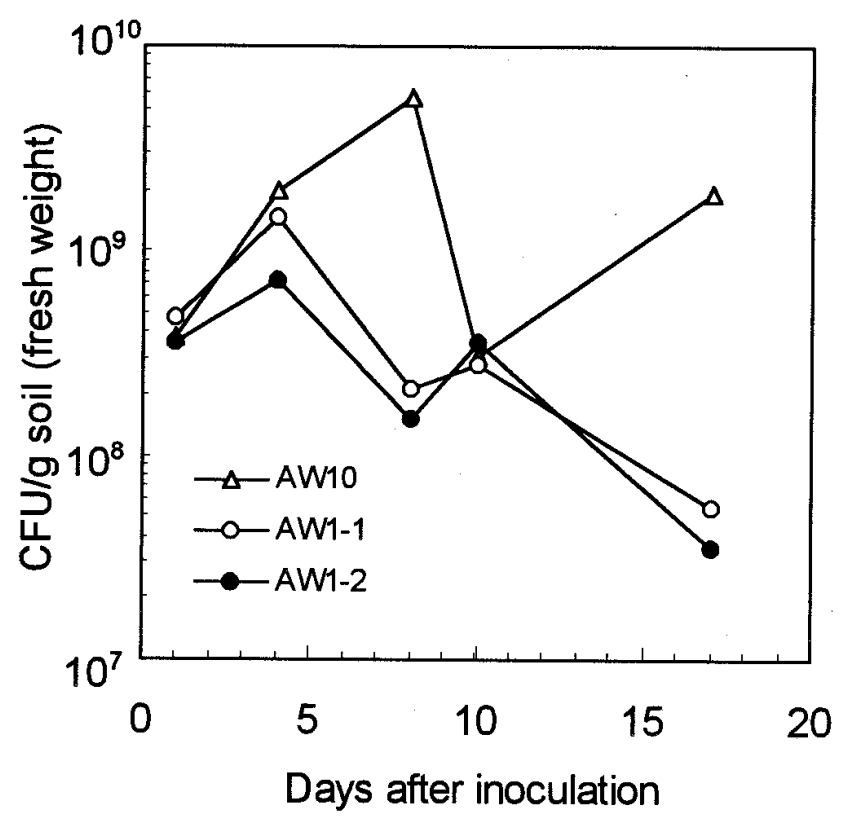

Fig. 2. Survival of Ralstonia solanacearum in rhizosphere soil. Initial inoculum concentrations were $3.5 \times 10^{8} \mathrm{CFU}$ per $\mathrm{g}$ of soil (wet weight) for AW10, $4.9 \times 10^{8} \mathrm{CFU}$ per $\mathrm{g}$ for AW1-1, and $4.6 \times 10^{8} \mathrm{CFU}$ per $\mathrm{g}$ for AW1-2. Four plants per strain were sampled at each time point. Analysis of variance showed that none of the strains were different at any sampling date. In a $t$ test, the decrease in the number of bacteria recovered on days 1 and 17 was significantly different only for AW1-2. 
ments, we investigated whether survival of AW10 and AW1-2 in the rhizosphere soil was different than in bulk soil, and we were unable to detect a difference during the 12 days after infestation (data not shown). This result is not surprising considering the high root mass in the Styrofoam cups, and it indicates that there is no clear difference between rhizosphere soil and bulk soil in our system. We also investigated survival of AW10 and AW1-2 in soil without plants by incubating cups with infested soil under standard growth chamber conditions. After 7 weeks, we recovered $2.1 \times$ $10^{6} \mathrm{CFU}$ of AW10 and $8.4 \times 10^{6} \mathrm{CFU}$ of AW1-2 per $\mathrm{g}$ of soil, which was a 200 -fold and a 70-fold decrease for these strains, respectively. These experiments showed that all four strains were equally available for infection within the first 2 weeks after soil infestation, well past the time at which symptoms developed in plants inoculated with the wild type.

Effectiveness of surface disinfestation methods. To quantify root invasion and infection by $R$. solanacearum after soil infestation, we needed a reliable method for surface disinfestation of primary roots that did not eliminate bacterial populations within the cortex and stele. Two different bleach treatments and one ethanol treatment were tested for their effect on the number of viable $R$. solanacearum cells that could be recovered from lateral or primary roots (i.e., lacking lateral roots) of young tomato plants. $R$. solanacearum was present in the primary roots of 83 to $100 \%$ of test plants, and since there was no difference between AW10 and AW1-1 in any treatment, the data for the two strains were combined (Table 2). Although the treatments did not affect viable cells recovered from the primary roots, the number of viable cells in lateral roots dropped below our theoretical threshold for detection (30 CFU per $g$ of root based on one colony counted from plating $100 \mu \mathrm{l}$ of homogenate) when treated with $1.0 \%$ sodium hypochlorite for $2 \mathrm{~min}$. Because this rigorous bleach treatment eliminated $R$. solanacearum both on the surface and inside the lateral roots, it likely kills most (if not all) of the bacteria on the surface of primary roots.

Invasion of primary roots after soil infestation. Invasion and subsequent multiplication were assessed by enumerating viable cells recovered from surface-disinfested primary roots 4 and $24 \mathrm{~h}$ after soil infestation with wild type and EPS ${ }^{-}$mutants (Table 3). After $4 \mathrm{~h}$, slightly more bacteria were recovered from the primary roots of plants inoculated with the double mutant AW1-2 than from those inoculated with AW10 and AW1-1. Twenty-four hours after soil infestation, the average numbers of bacteria per gram of primary root for all three strains had increased and were not significantly different from each other. In a second experiment, there was again no significant difference between the strains $24 \mathrm{~h}$ after soil infestation (data not shown). Thus, the ability of $R$. solanacearum to produce EPS I or EG does not appear to be a factor in penetration or colonization of tomato primary roots shortly after soil infestation.

In support of the data from viable cell-plating, we visualized bacteria with immunofluorescence in cross sections through pri-

TABLE 2. Numbers of viable Ralstonia solanacearum ${ }^{\mathrm{x}}$ cells recovered from surface-disinfested roots after soil infestation ${ }^{\mathrm{y}}$

\begin{tabular}{lccc}
\hline & \multicolumn{3}{c}{ Disinfestation treatment } \\
\cline { 2 - 4 } Roots & Ethanol rinse & $20 \%$ bleach, 30 s & $20 \%$ bleach, 2 min \\
\hline Primary & $6.2 \times 10^{3} \mathrm{a}^{\mathrm{z}}$ & $2.7 \times 10^{4} \mathrm{a}$ & $2.5 \times 10^{4} \mathrm{a}$ \\
Lateral & $1.4 \times 10^{6} \mathrm{a}$ & $2.1 \times 10^{4} \mathrm{~b}$ & $<30 \mathrm{~b}$ \\
\hline
\end{tabular}

${ }^{x}$ Numbers are CFU per $\mathrm{g}$ of plant tissue.

${ }^{y}$ Twenty-four hours after soil infestation with AW10 $\left(2.9 \times 10^{8}\right.$ CFU per g) or AW1-1 $\left(5.0 \times 10^{8} \mathrm{CFU}\right.$ per $\left.\mathrm{g}\right)$ the root systems of 18 plants were washed under running water and treated either with bleach or rinsed with $95 \%$ ethanol (six root systems per treatment). Primary roots and lateral roots were separated, homogenized, and plated to determine viable cell counts. Results from the two strains were similar, so the data were combined.

${ }^{\mathrm{z}}$ Means $(n=6)$ within a row followed by the same letter are not significantly different according to Duncan's multiple range test $(\alpha=0.05)$. mary roots of plants that were fixed $4 \mathrm{~h}$ after soil infestation. Based on our viable cell counts from previous experiments, at such an early time point, a single primary root should not contain more than several hundred bacteria. We repeatedly detected both AW10 and $E$. coli cells in 7- $\mu \mathrm{m}$ sections through the primary root cortex (Fig. 3). Cells were mostly single and only rarely in groups of three to five. The presence of $E$. coli in the cortex indicated that, under our experimental conditions, even a nonpathogenic bacterium quickly invaded roots of tomato plants grown in soil.

Colonization of plant stems after soil infestation. To investigate whether reduced virulence of the mutants (Fig. 1) was accompanied by fewer plants being systemically infected, we assayed primary roots and stems for the presence of $R$. solanacearum after soil infestation. In experiment 1 , we tested the wild type and all three mutants. For each strain, eight tissue samples were collected from each of 12 plants at 2, 5, and 12 days after soil infestation (the surface-disinfested primary root and seven $3-\mathrm{cm}$ stem pieces), the presence of viable $R$. solanacearum was determined, and the percentage of plant segments colonized at each height was plotted (Fig. 4). On day 2 (Fig. 4A), R. solanacearum was detected in 17 to $33 \%$ of the 12 surface-disinfested primary roots, but in the stem of only one plant (inoculated with AW10). The lower incidence of infected roots and the greater variation in the number of $R$. solanacearum recovered in comparison to the experiments described above (Table 3) was attributed to the use of 10-fold lower inoculum concentrations. The percentage of colonized primary roots (Fig. 4B and C), as well as the number of bacteria isolated from surface-disinfested roots, increased for all four strains on subsequent sampling dates. On days 5 and 12, the $\mathrm{EG}^{-}$mutant (PS6-4) colonized the stems of about half as many plants as the wild type, and the EPS ${ }^{-}$(AW1-1) and EPS $/$EG $^{-}$(AW1-2) mutant colonized only 10 to $20 \%$ by day 12 . In contrast, on day 12 , AW10 colonized 10 plants $(83 \%)$ from the primary roots to the top of the

TABLE 3. Invasion and colonization of tomato primary roots by Ralstonia solanacearum after soil infestation ${ }^{\mathrm{y}}$

\begin{tabular}{lccccc}
\hline & \multicolumn{2}{c}{$4 \mathrm{~h}$} & & \multicolumn{2}{c}{$24 \mathrm{~h}$} \\
\cline { 2 - 3 } \cline { 5 - 6 } Strain & CFU per g & \% infected & & CFU per g & \% infected \\
\hline AW10 & $6.2 \times 10^{2} \mathrm{~b}^{\mathrm{z}}$ & 100 & & $1.1 \times 10^{4} \mathrm{a}$ & 82 \\
AW1-1 & $2.0 \times 10^{2} \mathrm{~b}$ & 64 & & $1.4 \times 10^{4} \mathrm{a}$ & 100 \\
AW1-2 & $1.6 \times 10^{3} \mathrm{a}$ & 91 & & $5.9 \times 10^{3} \mathrm{a}$ & 91 \\
\hline
\end{tabular}

y Soil was infested with AW10 $\left(2.0 \times 10^{8}\right.$ CFU per g of soil $)$, AW1-1 $(2.3 \times$ $10^{8} \mathrm{CFU}$ per $\mathrm{g}$ of soil), and AW1-2 $\left(1.8 \times 10^{8} \mathrm{CFU}\right.$ per $\mathrm{g}$ of soil $)$ and plants processed 4 and $24 \mathrm{~h}$ later. Eleven root systems per strain and sampling time were washed under running tap water and bleached (1\% sodium hypochlorite, $2 \mathrm{~min}$ ), and the lateral roots were removed and discarded. The primary roots were then rinsed with $95 \%$ ethanol prior to weighing, homogenization, and plating for viable cell counts

${ }^{\mathrm{z}}$ Means $(n=11)$ within a column followed by the same letter are not significantly different according to Duncan's multiple range test $(\alpha=0.05)$.
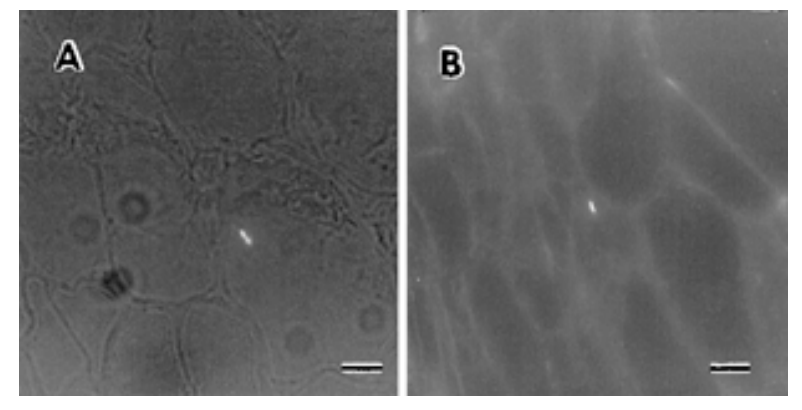

Fig. 3. Fluorescence micrographs of bacteria in the cortex of tomato primary roots. A, Ralstonia solanacearum AW10 $(\mathrm{bar}=3 \mu \mathrm{m})$ and $\mathbf{B}$, Escherichia coli DH5 $\alpha(\mathrm{pUC19})(\mathrm{bar}=6 \mu \mathrm{m})$. The soil of potted tomato plants was infested with AW10 $\left(3.74 \times 10^{8} \mathrm{CFU}\right.$ per g of soil) and DH5 $\alpha$ (pUC19) $(1.24 \times$ $10^{8} \mathrm{CFU}$ per $\mathrm{g}$ of soil) $4 \mathrm{~h}$ prior to fixation. 

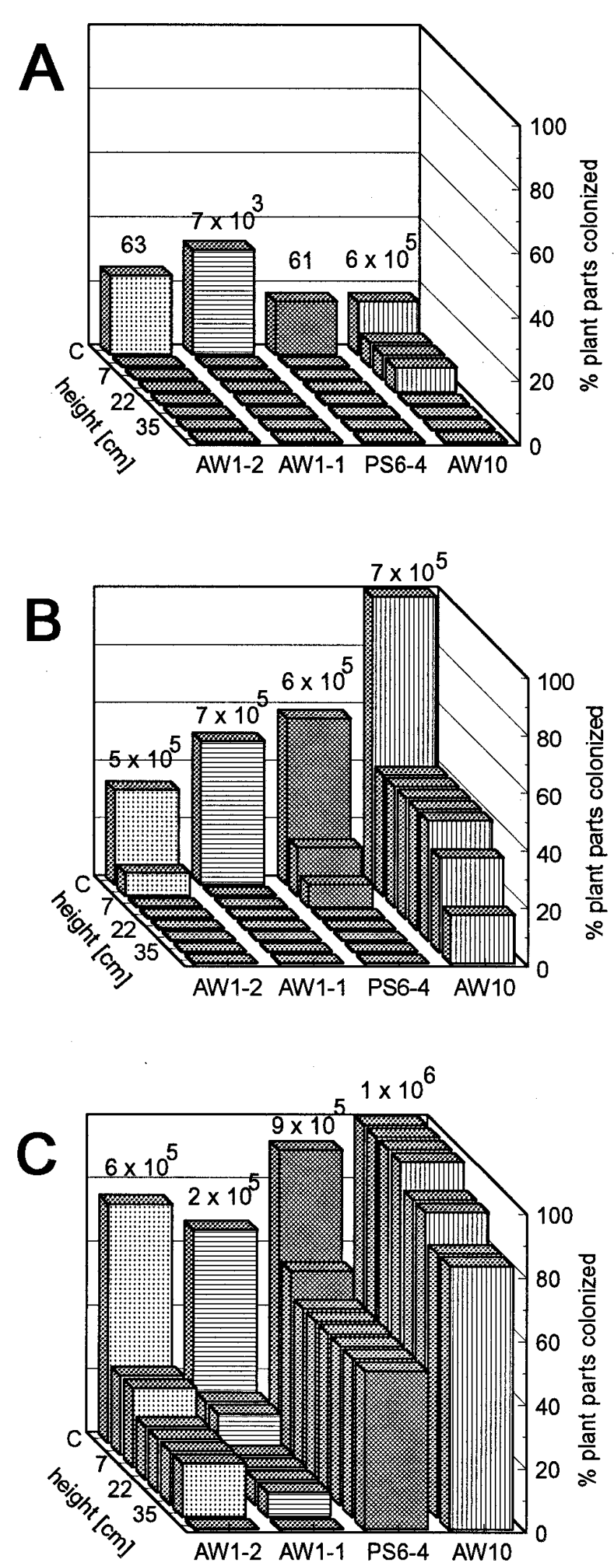

Fig. 4. Colonization of tomato primary roots and stems after soil was infested with Ralstonia solanacearum: in experiment 1, plants were sampled A, 2 days; B, 5 days; or $\mathbf{C}, 12$ days after soil infestation. On the height axis, "C" represents the surface-sterilized primary root plus $1 \mathrm{~cm}$ of hypocotyl. The 7-cm mark represents the second 3-cm stem piece above the primary root. All other height values refer to distance of the lower edge of the $3-\mathrm{cm}$ stem segment from the soil line. Numbers above bars represent mean CFU per $\mathrm{g}$ of primary root. Inoculum concentrations (in CFU per $\mathrm{g}$ of soil) were $1.5 \times 10^{7}$ for AW10, $1.6 \times 10^{7}$ for PS6-4, $2.9 \times 10^{7}$ for AW1-1, and $1.4 \times 10^{7}$ for AW1-2. stems $(45 \mathrm{~cm})$, one plant was colonized only up to $28 \mathrm{~cm}$, and one plant only to $15 \mathrm{~cm}$.

Statistical analysis of incidence data for experiment 1 using PROC NPAR1WAY and the Wilcoxon rank-sum test showed significant differences between AW10 and all three mutants on days 5 and 12 (Table 4). On day 12, PS6-4 also was different from AW1-1 and AW1-2. When using PROC GLM, CONTRAST statements to compare $\mathrm{EPS}^{+}$strains (AW10 and PS6-4) and EPS ${ }^{-}$strains (AW1-1 and AW1-2), and $\mathrm{EG}^{+}$(AW10 and AW1-1) and $\mathrm{EG}^{-}$ strains (PS6-4 and AW1-2) were significant $(P<0.02)$ on days 5 and 12. Thus, in experiment 1 , EPS I and EG both contributed to the ability of $R$. solanacearum to colonize the stems of tomato plants after soil infestation.

Additional soil infestation experiments tested different combinations of strains or different inoculum concentrations (Table 4). In experiment 2, AW10 colonized the plant stems significantly faster than AW1-1 on days 4 and 11. In experiment 3, we used 10-fold higher inoculum concentrations and found that AW10 was significantly different from all three mutants on day 4. On day 11, the wild-type AW10 was different from AW1-1 and AW1-2, but not from PS6-4. There was not a significant difference between the two EPS ${ }^{-}$strains (AW1-1 and AW1-2) in any of the experiments (data not shown). Therefore, AW10 and PS6-4 consistently colonized plants from the transition zone towards the apex significantly faster than did the two EPS ${ }^{-}$mutants AW1-1 and AW1-2.

Colonization of plant stems after petiole inoculation. If the difference observed between the wild type and the mutant strains in colonizing plants after soil infestation occurs within the stems rather than during entry or multiplication within the roots, then we would also expect to see differential colonization of the stem after petiole inoculation. To test this possibility, we inoculated plants by depositing a $2-\mu l$ droplet of inoculum on the cut surface of a petiole severed $5 \mathrm{~mm}$ from the stem. At intervals after inoculation, the petiole stub was removed and discarded and the 3-cm section of stem at the base of each inoculated petiole $(1.5 \mathrm{~cm}$ above and below; section I) was sampled for viable cell counts. One day after inoculation, all four $R$. solanacearum strains had invaded the stem and, between days 1 and 6 , the number of viable cells recovered increased over four to five orders of magnitude (Table 5). However, despite inoculum concentrations for the mutants being at least as high as for AW10, viable counts for the EPS ${ }^{-}$mutants AW1-1 and AW1-2 were significantly lower than for the wild type on both sampling dates. Thus, the mutants appeared to be defective in colonizing the stem from the petiole inoculation site, but, once inside the stem, they multiplied as rapidly as the wild type.

To examine the time course of colonization along the vertical plant axis, we assayed stem pieces above and below the inoculated petiole for the incidence of $R$. solanacearum on days 1,6 , and 14 . In three experiments, all four strains colonized the plant stems in both directions, but analysis of variance and the nonparametric

TABLE 4. Wilcoxon rank-sum test $P$ values for pairwise comparisons in three soil infestation experiments ${ }^{\mathrm{w}}$

\begin{tabular}{|c|c|c|c|c|c|c|}
\hline \multirow[b]{2}{*}{ Comparison } & \multicolumn{2}{|c|}{ Experiment 1} & \multicolumn{2}{|c|}{ Experiment $2^{\mathrm{x}}$} & \multicolumn{2}{|c|}{ Experiment 3} \\
\hline & 5 days & 12 days & 4 days & 11 days & 4 days & 11 days \\
\hline AW10 vs. PS6-4 & $0131 \%$ & $0.0418^{*}$ & $\mathrm{ND}^{\mathrm{z}}$ & ND & $0.0425^{*}$ & 0.5938 \\
\hline AW1-1 & $0.0013^{*}$ & $0.0001^{*}$ & $0.0497 *$ & $0.0005^{*}$ & $0.0160 *$ & $0.0184 *$ \\
\hline AW10 vs. AW1-2 & $0.0010 *$ & $0.0001 *$ & ND & ND & $0.0083^{*}$ & $0.0029 *$ \\
\hline PS6-4 vs. AW1-1 & 0.4603 & $0.0165^{*}$ & ND & ND & 0.1767 & $0.0043 *$ \\
\hline PS6-4 vs. AW1-2 & 0.2338 & $0.0394 *$ & 0.1911 & 0.2681 & 0.0759 & $0.0006^{*}$ \\
\hline
\end{tabular}

${ }^{\mathrm{w}}$ Inoculum concentrations (CFU per $\mathrm{g}$ of soil) in experiment 1 ranged from 1.4 to $2.9 \times 10^{7}$; in experiment 2 , from $7.7 \times 10^{6}$ to $2.2 \times 10^{7}$; and, in experiment 3 , from 3.3 to $9.9 \times 10^{8}$.

${ }^{x}$ Experiment 2 is the result from two identical experiments using different pairs of strains: AW10 was tested against AW1-1, and PS6-4 was tested against AW1-2.

y $*$ denotes significant difference at $P<0.05$.

${ }^{\mathrm{z}} \mathrm{ND}=$ not done 
Kruskal-Wallis test revealed significant differences in percentage of plant parts colonized only on day 6. The Wilcoxon rank-sum test was then run for all possible pairwise combinations of strains on that day (Table 6). When inoculated with 7 to $9 \times 10^{5} \mathrm{CFU}$ in experiment 1 , there was a significant difference between AW10 and the double mutant AW1-2 and between the EG ${ }^{-}$strains PS6-4 and AW1-2. In experiment 2, the inoculum concentration was reduced by $80 \%$ and strains AW10, AW1-1, and AW1-2 were examined on days 1 and 6 . On day 1 , bacteria were detected only in the $3 \mathrm{~cm}$ at the base of the inoculated petiole (section I), but 80 to $100 \%$ of the stems were infected (data not shown). On day 6, the percentage of stems infected by each strain was unchanged, but AW10 had colonized $80 \%$ of the sections above and below section I (Fig. $5 \mathrm{~A}$ ), whereas AW1-1 had migrated into the rest of the stem in only $20 \%$ of the plants and AW1-2 had not systemically colonized any plant (Fig. 5B and C). Based on these incidence data, AW10 was significantly different from AW1-1 $(P=0.0377)$ and from AW1-2 $(P=0.0209)$ on day 6 (Table 6). Examination of viable cell counts for these samples showed that, on day 6 , the wild type had reached densities of $>2 \times 10^{7} \mathrm{CFU}$ per $\mathrm{g}$ of stem in all but one of the plants (Fig. 5A). Both AW1-1 and AW1-2 multiplied less than the wild type in section I and elsewhere in the stem (Fig. 5B and C).

Similar results were obtained in petiole inoculation experiment 3 , in which only AW10 and AW1-1 were examined on days 1 and 6 (Table 6). These experiments support our conclusion that EPS I and EG are not required, but facilitate migration from the cut surface of an excised petiole into stem tissue and play a role in subsequent systemic colonization of the stem.

\section{DISCUSSION}

We used two different inoculation methods to test the importance of EPS I and EG during different stages of pathogenesis. The soil infestation method examined whether these virulence factors play a role in the process of ingress into undisturbed roots of tomato plants and the subsequent colonization of their stems. Both wild type and well-defined mutant strains of $R$. solanacearum were recovered from surface-disinfested primary roots as little as $4 \mathrm{~h}$ after soil infestation. In light of our rigorous disinfestation proce-

TABLE 5. Colonization by Ralstonia solanacearum of the $3-\mathrm{cm}$ stem section at the base of inoculated petioles in experiment $1^{\mathrm{y}}$

\begin{tabular}{lcl}
\hline Strain & Day 1 & Day 6 \\
\hline AW10 & $1.6 \times 10^{6} \mathrm{a}^{\mathrm{z}}$ & $2.8 \times 10^{11} \mathrm{a}$ \\
PS6-4 & $6.0 \times 10^{5} \mathrm{~b}$ & $2.2 \times 10^{11} \mathrm{a}$ \\
AW1-1 & $2.3 \times 10^{4} \mathrm{~b}$ & $6.5 \times 10^{9} \mathrm{~b}$ \\
AW1-2 & $2.6 \times 10^{5} \mathrm{~b}$ & $6.0 \times 10^{9} \mathrm{~b}$ \\
\hline
\end{tabular}

y Inoculum concentrations (CFU per $2 \mu \mathrm{l})$ were $7.1 \times 10^{5}$ for AW10, $9.6 \times$ $10^{5}$ for AW1-1, $7.4 \times 10^{5}$ for AW1-2, and $8.6 \times 10^{5}$ for PS6-4. Values are CFU per $g$ of stem.

${ }^{\mathrm{z}}$ Means $(n=6)$ within a column followed by the same letter are not significantly different according to Duncan's multiple range test $(\alpha=0.05)$.

TABLE 6. Wilcoxon rank-sum test $P$ values for pairwise comparisons of strains at sampling day 6 from three petiole inoculation experiments ${ }^{\mathrm{x}}$

\begin{tabular}{lccc}
\hline Comparison & Experiment 1 & Experiment 2 & Experiment 3 \\
\hline AW10 vs. PS6-4 & 0.753 & ND $^{\mathrm{y}}$ & $\mathrm{ND}$ \\
AW10 vs. AW1-1 & 0.128 & $0.038^{*}$ & $0.004^{*}$ \\
AW10 vs. AW1-2 & $0.016^{* \mathrm{z}}$ & $0.021^{*}$ & $\mathrm{ND}$ \\
PS6-4 vs. AW1-1 & 0.085 & $\mathrm{ND}$ & $\mathrm{ND}$ \\
PS6-4 vs. AW1-2 & $0.015^{*}$ & $\mathrm{ND}$ & $\mathrm{ND}$ \\
AW1-1 vs. AW1-2 & 0.203 & 0.233 & $\mathrm{ND}$ \\
\hline
\end{tabular}

${ }^{\mathrm{x}}$ Inoculum concentrations (CFU per plant) in experiment 1 ranged from 7.1 to $9.5 \times 10^{5}$; in experiment 2 , from 1.1 to $1.5 \times 10^{5}$; and, in experiment 3 , from 6.6 to $8.6 \times 10^{4}$.

y $\mathrm{ND}=$ not done.

$\mathrm{z} *$ denotes significant difference at $P<0.05$. dure and the microscopic detection of $R$. solanacearum within the cortex, we believe that the viable cells recovered from these primary roots had penetrated the epidermal layer. Thus, neither EPS I nor EG appear to be essential for rapid ingress of $R$. solanacearum into tomato roots. In fact, invasion of tomato roots may be largely nonspecific, since we also observed $E$. coli microscopically within the root cortex $4 \mathrm{~h}$ after soil infestation. This possibility is supported by the wide variety of bacteria that have been found inside roots, stems, fruit, and seeds of apparently healthy plants $(5,12,24)$. Lamb et al. (25) present evidence for root penetration and subsequent stem colonization by the nonpathogenic rhizobacter-
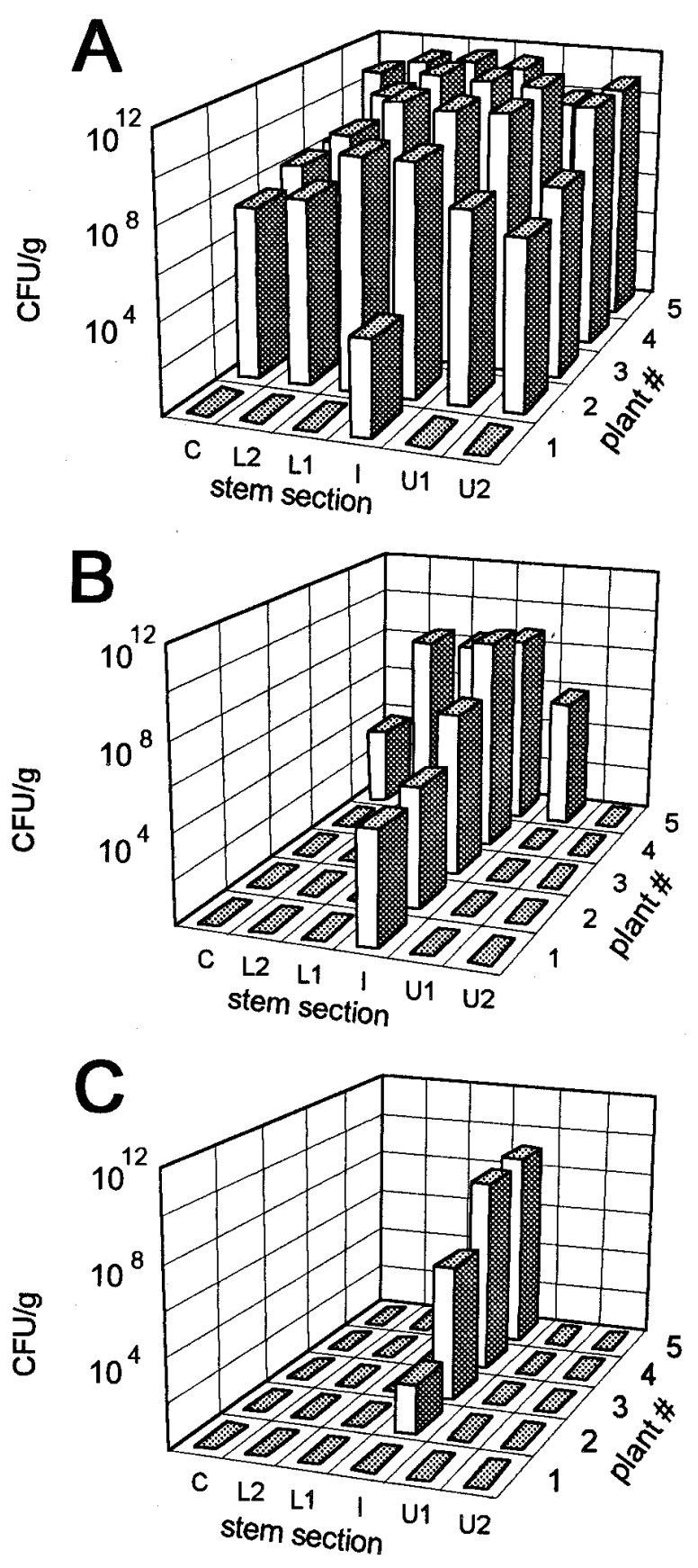

Fig. 5. Colonization of tomato stems after petiole inoculation with Ralstonia solanacearum: in experiment 2 , day 6 , viable cell data. Plants were inoculated with A, AW10 $\left(1.5 \times 10^{5} \mathrm{CFU}\right) ; \mathbf{B}, \mathrm{AW} 1-1\left(1.1 \times 10^{5} \mathrm{CFU}\right)$; and C, AW1-2 $\left(1.2 \times 10^{5} \mathrm{CFU}\right)$. Five plants were sampled per strain. In addition to the stem piece from $1.5 \mathrm{~cm}$ above to $1.5 \mathrm{~cm}$ below the base of the inoculated petiole (I), 3-cm sections from 1.5 to $4.5 \mathrm{~cm}$ and from 4.5 to $7.5 \mathrm{~cm}$ above (U1 and U2) and below (L1 and L2) the base of the inoculated petiole were assayed. "C" represents the primary root plus $1 \mathrm{~cm}$ of hypocotyl. 
ium Pseudomonas aureofaciens in corn, and movement from roots to the stems within $24 \mathrm{~h}$ suggests vascular transport of the bacteria.

After root invasion, we observed that wild type and mutant $R$. solanacearum strains differed in their ability to quickly colonize tomato stems. The EPS ${ }^{-}$strains (AW1-1 and AW1-2) systemically colonized tomato stems significantly slower than the $\mathrm{EG}^{-}$mutant (PS6-4), which itself colonized plants significantly slower than the wild type. Thus, the loss of either EPS I or EG resulted in reduced virulence, as judged by wilt symptoms, and reduced stem colonization. Since the EPS ${ }^{-}$mutant was more incapacitated than the $\mathrm{EG}^{-}$mutant in both wilting and colonization, this suggests that EPS I is more important in both phases of pathogenesis than is EG. Although EPS ${ }^{-}$mutants were able to wilt all the leaves of one to two out of 10 susceptible tomato plants after soil infestation, the underlying mechanism appears to be different from wilt caused by $\mathrm{EPS}^{+}$strains, because symptoms develop later, the process is slower, and there is visible discoloration and extensive maceration of the pith. It is likely that additional, unidentified virulence determinants contribute to colonization and disease development $(31,32$; J. A. McGarvey, unpublished data).

The petiole inoculation method also showed that EPS I has an important function in facilitating the rapid spread of bacteria within stems of susceptible tomato plants. In contrast to the soil infestation method, it seems that only EPS ${ }^{-}$mutants were significantly different from the wild type when introduced via cut petioles, and the differences were only significant on day 6. However, strain PS6-4 was only tested once, and our suggested interpretation that the smaller and transient differentials between wild type and mutant strains after petiole inoculations likely are due to the bacteria directly invading broken xylem vessels in petioles, whereas, after soil infestation, they must move through the root cortex and stele, penetrate xylem vessels, and then pass through the vascular transition zone into the stem, should be regarded as preliminary. Although EPS I appears to enhance colonization of tomato stems by $R$. solanacearum, it seems to be more important during colonization of roots.

Rapid systemic distribution of EPS I-producing bacteria in the stem and development of large bacterial populations in various regions of the plant body appear to be required for typical wilt symptoms. After the roots were infected, we observed that tomato plants did not begin to wilt until the wild-type $R$. solanacearum had colonized the entire length of the stem, but then wilting was rapid (1 to 2 days) and plants never recovered (E. Saile, unpublished data). In addition to our results with $\mathrm{EPS}^{-}$mutants, poor colonization of tomato stems, which is associated with low virulence, has been reported for hrp mutants in a susceptible cultivar (37) and a wildtype strain in bacterial wilt-resistant cultivars (29; J. A. McGarvey, T. P. Denny, and M. A. Schell, unpublished data). Even though, in both cases, the $R$. solanacearum strains are EPS ${ }^{+}$, they do not effectively colonize the upper half of tomato stems and either do not cause wilt (hrp mutants) or induce less wilt. Thus, EPS I is important but it is not sufficient for colonization.

We do not know yet why EPS ${ }^{-}$mutants colonize tomato stems less successfully than the wild type, but EPS I might facilitate movement of the bacterium in planta, protect the bacterium from plant defense reactions, or both (7). Several other studies have suggested that EPS enhances pathogen survival or colonization of host tissues by phytopathogenic bacteria. For example, EPS-deficient mutants of Erwinia amylovora $(27,36)$ and Xanthomonas campestris pv. citrumelo (23) could not be recovered from apple and citrus leaves, respectively, several days after inoculation, and Erwinia stewartii mutants appear to be colonization defective (3). Our challenge now is to determine more precisely how EPS I promotes colonization of tomato plants by $R$. solanacearum. Improved labeling techniques for in situ observation of bacteria in plant tissue and more sophisticated use of reporter gene fusions should enable us to address these complex questions.

\section{ACKNOWLEDGMENTS}

This work was supported by U.S. Department of Agriculture NRICGP grant 94-37303-7753, and by State and Hatch funds awarded by the University of Georgia Agriculture Experiment Station.

\section{LITERATURE CITED}

1. Boucher, C. A., Barberis, P. A., Trigalet, A. Ph., and Demery, D. A. 1985. Transposon mutagenesis of Pseudomonas solanacearum: Isolation of Tn5-induced avirulent mutants. J. Gen. Microbiol. 131:2449-2457.

2. Boucher, C. A., Gough, C. L., and Arlat, M. 1992. Molecular genetics of pathogenicity determinants of Pseudomonas solanacearum with special emphasis on hrp genes. Annu. Rev. Phytopathol. 30:443-461.

3. Braun, E. J. 1990. Colonization of resistant and susceptible maize plants by Erwinia stewartii strains differing in exopolysaccharide production. Physiol. Mol. Plant Pathol. 36:363-379.

4. Buddenhagen, I., and Kelman, A. 1964. Biological and physiological aspects of bacterial wilt caused by Pseudomonas solanacearum. Annu. Rev. Phytopathol. 2:203-230.

5. Chanway, C. P. 1996. Endophytes: They're not just fungi! Can. J. Bot. 74:321-322.

6. Clough, S. J., Flavier, A. B., Schell, M. A., and Denny, T. P. 1997. Differential expression of virulence genes and motility in Ralstonia (Pseudomonas) solanacearum during exponential growth. Appl. Environ. Microbiol. 63:844-850.

7. Denny, T. P. 1995. Involvement of bacterial polysaccharides in plant pathogenesis. Annu. Rev. Phytopathol. 33:173-197.

8. Denny, T. P., and Baek, S.-R. 1991. Genetic evidence that extracellular polysaccharide is a virulence factor of Pseudomonas solanacearum. Mol. Plant-Microbe Interact. 4:198-206.

9. Denny, T. P., Carney, B. F., and Schell, M. A. 1990. Inactivation of multiple virulence genes reduces the ability of Pseudomonas solanacearum to cause wilt symptoms. Mol. Plant-Microbe Interact. 3:293-300.

10. Denny, T. P., Makini, F. W., and Brumbley, S. M. 1988. Characterization of Pseudomonas solanacearum Tn5 mutants deficient in extracellular polysaccharide. Mol. Plant-Microbe Interact. 1:215-223.

11. Devi, L. R., Menon, M. R., and Aiyer, R. S. 1981. Survival of Pseudomonas solanacearum in soil. Plant Soil 62:169-182.

12. Di Fiore, S., and Del Gallo, M. 1995. Endophytic bacteria: Their possible role in the host plant. NATO ASI (Adv. Sci. Inst.) Ser. G Ecol. Sci. 37:169-187.

13. Dukes, P. D., Jenkins, S. F., Jr., Jaworski, C. A., and Morton, D. J. 1965. The identification and persistence of an indigenous race of Pseudomonas solanacearum in a soil in Georgia. Plant Dis. Rep. 49:586-590.

14. Granada, G. A., and Sequeira, L. 1983. Survival of Pseudomonas solanacearum in soil, rhizosphere, and plant roots. Can. J. Microbiol. 29:433-440.

15. Grimault, V., Anais, G., and Prior, P. 1994. Distribution of Pseudomonas solanacearum in the stem tissues of tomato plants with different levels of resistance to bacterial wilt. Plant Pathol. 43:663-668.

16. Hayward, A. C. 1991. Biology and epidemiology of bacterial wilt caused by Pseudomonas solanacearum. Annu. Rev. Phytopathol. 29:65-87.

17. Jackson, M. T., and González, L. C. 1981. Persistence of Pseudomonas solanacearum (race 1) in a naturally infested soil in Costa Rica. Phytopathology 71:690-693.

18. Kang, Y., Huang, J., Mao, G., He, L.-Y., and Schell, M. A. 1994. Dramatically reduced virulence of mutants of Pseudomonas solanacearum defective in export of extracellular proteins across the outer membrane. Mol. Plant-Microbe Interact. 7:370-377.

19. Kao, C. C., Barlow, E., and Sequeira, L. 1992. Extracellular polysaccharide is required for wild-type virulence of Pseudomonas solanacearum. J. Bacteriol. 174:1068-1071.

20. Kelman, A. 1953. The bacterial wilt caused by Pseudomonas solanacearum. Calif. Agric. Exp. Stn. Bull. 99:1-194.

21. Kelman, A., Hartman, G. L., and Hayward, A. C. 1994. Introduction. Pages 1-7 in: Bacterial Wilt: The Disease and Its Causative Agent, Pseudomonas solanacearum. A. C. Hayward and G. L. Hartman, eds. CAB International, Wallingford, United Kingdom.

22. Kelman, A., and Sequeira, L. 1965. Root-to-root spread of Pseudomonas solanacearum. Phytopathology 55:304-309.

23. Kingsley, M. T., Gabriel, D. W., Marlow, G. C., and Roberts, P. D. 1993. The ops X locus of Xanthomonas campestris affects host range and biosynthesis of lipopolysaccharide and extracellular polysaccharide. J. Bacteriol. 175:5839-5850.

24. Kloepper, J. W., Schippers, B., and Bakker, P. A. H. M. 1992. Proposed elimination of the term endorhizosphere. Phytopathology 82:726-727.

25. Lamb, T. G., Tonkyn, D. W., and Kluepfel, D. A. 1996. Movement of Pseudomonas aureofaciens from the rhizosphere to aerial plant tissue. Can. J. Microbiol. 42:1112-1120. 
26. Maniatis, T., Fritsch, E. F., and Sambrook, J. 1982. Molecular Cloning: A Laboratory Manual. Cold Spring Harbor Laboratory, Cold Spring Harbor, NY.

27. Norelli, J. L., Gilbert, M. T., Aldwinckle, H. S., Zumoff, C. H., and Beer, S. V. 1990. Population dynamics of nonpathogenic mutants of Erwinia amylovora in apple host tissue. Acta Hortic. 273:239-240.

28. Orgambide, G., Montrozier, H., Servin, P., Roussel, J., Trigalet-Demery, D., and Trigalet, A. 1991. High heterogeneity of the exopolysaccharides of Pseudomonas solanacearum strain GMI 1000 and the complete structure of the major polysaccharide. J. Biol. Chem. 266:8312-8321.

29. Prior, P., Leclerq, S., Bart, S., Darrasse, A., and Anais, G. 1996. Resistance to bacterial wilt in tomato as discerned by spread of Pseudomonas (Burkholderia) solanacearum in stem tissues. Plant Pathol. 45:720-726.

30. Roberts, D. P., Denny, T. P., and Schell, M. A. 1988. Cloning of the egl gene of Pseudomonas solanacearum and analysis of its role in phytopathogenicity. J. Bacteriol. 170:1445-1451.

31. Schell, M. A. 1996. To be or not to be: How Pseudomonas solanacearum decides whether or not to express virulence genes. Eur. J. Plant Pathol. 102:459-469.

32. Schell, M. A., Denny, T. P., and Huang, J. 1994. VsrA, a second twocomponent system regulating virulence genes of Pseudomonas solanacearum. Mol. Microbiol. 11:489-500.

33. Schmit, J. 1978. Microscopic study of early stages of infection by Pseu- domonas solanacearum E.F.S. on "in vitro" grown tomato seedlings. Pages 841-857 in: Proc. Int. Conf. Plant Pathogenic Bacteria, 4th.

34. Sequeira, L. 1993. Bacterial wilt: Past, present, and future. Pages 12-21 in: Bacterial Wilt. ACIAR Proc. 45. G. L. Hartman and A. C. Hayward, eds. Australian Centre for International Agriculture Research, Canberra.

35. Swanepoel, A. E. 1992. Survival of South African strains of biovar 2 and biovar 3 of Pseudomonas solanacearum in the roots and stems of weeds. Potato Res. 35:329-332.

36. Tharaud, M., Menggad, M., Paulin, J. P., and Laurent, J. 1994. Virulence, growth, and surface characteristics of Erwinia amylovora mutants with altered pathogenicity. Microbiology (United Kingdom) 140:659-669.

37. Trigalet, A., and Demery, D. 1986. Invasiveness in tomato plants of Tn5induced avirulent mutants of Pseudomonas solanacearum. Physiol. Mol. Plant Pathol. 28:423-430.

38. Vasse, J., Frey, P., and Trigalet, A. 1995. Microscopic studies of intercellular infection and protoxylem invasion of tomato roots by Pseudomonas solanacearum. Mol. Plant-Microbe Interact. 8:241-251.

39. Yabuuchi, E., Kosako, Y., Yano, I., Hotta, H., and Nishiuchi, Y. 1995. Transfer of two Burkholderia and an Alcaligenes species to Ralstonia gen. nov.: Proposal of Ralstonia pickettii (Ralston, Palleroni and Doudoroff 1973) comb. nov., Ralstonia solanacearum (Smith 1896) comb. nov. and Ralstonia eutropha (Davis 1969) comb. nov. Microbiol. Immunol. 39:897-904. 